\title{
Qualitative Analysis of the Determinants of Malnutrition among Children Under-five in Households in the Mayo-Danay Division, Cameroon
}

\author{
André Izacar Gaël Bita1, Benjamin Azike Chukuwchindun², Thomas Eddy Biwole \\ Omgba $^{3}$, Agbor Nyenty Agbornkwai ${ }^{4}$, Justin Bienvenu Eyong ${ }^{5}$, Martin Sobze Sanou ${ }^{6}$ \\ ${ }^{1,5,6}$ Catholic University of Central Africa, School of Health Sciences, Yaounde, Cameroon \\ ${ }^{2}$ Dutch Development Organization (SNV), Department of Monitoring and Evaluation, Yaounde, Cameroon \\ ${ }^{3}$ University of Yaounde 1, Department of Sociology, Yaounde, Cameroon \\ ${ }^{4}$ University of Dschang, Faculty of Medicine and Pharmaceutical Sciences, Dschang, Cameroon \\ bitagael@gmail.com
}

\begin{abstract}
The Far North region has the highest rate of chronic malnutrition (35.9\%) ahead of East (35.4\%); North (30.6\%) and Adamawa (28.7\%). The study aimed to identify contextual factors of child malnutrition in line with UNICEF's causal pattern of malnutrition (2013). This was a qualitative study. Multiple case sampling of social micro-units was used. Focus-groups; face-to-face interviews and observations were organized. Seguin method was used for data analysis (2010). Fifty people participated in the study. Mayo-danay is a landlocked area, where the lack of food processing and food conservation infrastructure promotes early and low-cost liquidation of food products. A situation that exposes families to famine and poverty a few months after the harvest. The influx of internally displaced persons (IDPs); insecurity due to terrorism has weakened cross-border trade. The household size is up to 10 members, that did not allow children to eat at their convenience, and in a diverse way. The Christian head of households did not systematically contribute to the food ration, unlike the Muslims. Fish, agricultural and livestock products are more for sale than for consumption in the household. There are frequent shortages of food supplements for the management of malnutrition in health training. The causes of malnutrition in Mayo-Danay were multifactorial. Strategies to fight against malnutrition must take into account the integrated approach to local and sustainable development.
\end{abstract}

Keywords: determinants of malnutrition; cameroon; causes of malnutrition; nutrition; risk factors for malnutrition

\section{Introduction}

Malnutrition has claimed victims for decades in several regions of the world and remains a public health problem. In 1995, nearly 55\% of child deaths associated with malnutrition (UNICEF, 1998), in 2019, the situation has not changed to much in developing countries. The number of children suffering from acute malnutrition remained high with nearly 50 million children wasted; 149 million were still stunted; hundreds of millions of children and women suffered from unsuspected hunger due to vitamin and mineral deficiencies, and overweight rates are rising rapidly (UNICEF, 2019). Increasingly, communities face a triple burden of malnutrition. Despite declining global statistics, numbers are increasing in Africa. Indeed, although there is a decline in the prevalence of stunting on the continent, the number of children with this pathology, driven by population growth, has increased from 50.6 million in 2000 to 58.7 million in 2017 (UNICEF, 2018). 
The results of recent surveys in Cameroon have revealed a stagnating trend in the prevalence of chronic malnutrition in children under five. According to data provided from the SMART surveys (MINSANTE, 2018), the Far North region (35.9\%) has the highest chronic malnutrition rate, followed by Adamawa (28.7\%), the North (30.6\%) and the East (35.4\%). The SMART (2019), specifies that with respectively $1.5 \%$, the Far North also has the highest prevalence of severe acute malnutrition in the North. According to the same source, the far north has an overall acute malnutrition prevalence of 5.2\% (MINSANTE, 2019), down from the $10.1 \%$ rate mentioned in the Demographic Health Surveys (DHS, 2018).

Several previous studies, notably the Unicef report (1998), the work of Pemunta NV and Fubah MA (Pemunta, 2014); by Alhaji A A and coll. (Alhadji,2012); Balogun TB and Yakubu AM (Balogun, 2014) and Keino S and coll. (Keino, 2014), Ramadhani and coll., (N. Ramadhani, 2020) already elucidated some causes of malnutrition, in order to propose elements of response for a policy to reduce the consequences of malnutrition in the world, particularly in developing countries.

According to Malnutrition Conceptual Framework developed in 2013 (UNICEF,2013), the root causes of malnutrition are directly related to the quality and quantity of existing resources (human, economic and organizational) and their controls. Underlying causes include lack of access to food and economics, inadequate care for mothers and children. As a result, people from low-income households are the most affected. Crisis situations and problems with the management of equitable natural resources are all factors that reinforce inequalities in access to quality food. All of these conditions have serious consequences on the survival, morbidity and capacity of individuals, the economy and a prosperous society (IFPRI, 2014). Mother's nutrition behaviors and attitudes are directly related to certain socioeconomic, cultural and environmental factors such as access to safe drinking water; mother's level of education, which are themselves linked to child malnutrition (Kadam A.M, 2007; Alhadji, 2012). However, the determinants of malnutrition differ from cultural, religious and geographic backgrounds (Ngo Um-Sap and al, 2014).

Effectiveness of a health program depends largely on the ability to understand the processes responsible for high levels of a phenomenon (Barbieri M., 1991). Several studies have been conducted in Cameroon, at national and/or regional level, describing the distributions of malnutrition in the country. These studies show persistently high prevalences of stunting reflecting the endemicity of malnutrition in the Far North region. In such a context of endemic malnutrition in the Far North region, causes were limited access to resources. We found it appropriate to analyze the causes of malnutrition in children under five years of age among mothers in the Mayo Danay Division.

\section{Materials and Methods}

\subsection{Study Scheme}

This is qualitative research on child (from 6 to 59 months) malnutrition determinants analysis in the Mayo-Danay division through focus groups with malnourished mothers of children in health facilities; semi-structured interviews with mothers, community leaders and observations in mothers' households and health facilities.

\subsection{Sample}

This was a multiple-case sampling of social micro-units. Groups were formed in a heterogeneous and at the same time homogeneous way allowing a plurality of opinions. To ensure heterogeneity in the focus groups we have included in each group, mothers of 
different religious origin and different neighborhoods/villages. Homogeneity was ensured by the exclusive participation of mothers of malnourished children in group discussions. The selection criteria for the sample to be selected were discussed during study planning with a multidisciplinary team of 02 nutritionists, 01 sociologists, 01 public health professionals and 01 physicians. Thus, it was agreed to take into account the following criteria and elements: (1) Coverage of all Mayo-Danay health districts (Yagoua, Kar-Hay, Maga, Guere and Vele); (2) Taking different religions and ethnic groups into account in focus groups; (3) Taking into account the status of mothers with a history of malnourished children; (4) Taking into account the availability of an outpatient nutritional center in the community; (5) Knowledge of the study environment (community leaders) for semi-direct discussions.

\subsection{Methodology Followed in the Field Survey}

The methodological approach adopted was based on a socio-anthropological approach whose primary purpose was to make mothers population to be actors of the analysis of the nutritional situation of their children. It is a form of interactive participation, information exchange and rewarding dynamics of expertise and knowledge of mothers, allowing the populations concerned to express their own perception of the local determinants of malnutrition in the community. This approach identified the problem of the joint study in accordance with the causal pattern of malnutrition and built the information collection plan and the report.

\subsection{Data collection}

The study focused on collecting data in the four health districts (HD) of the division of Mayo Danay, including Yagoua HD, Kar-Hay HD, Maga HD, Guere HD and Vele HD. The techniques that were applied during the field survey were:

- Group discussions, a technic that allowed in-depth discussions with groups of malnourished mothers in nutritional centers in health districts. In the same group the mothers had the same social characteristics based on a detailed grid of objectives and information sought. The discussions were held in a quiet, spacious place away from the eyes and men and health workers. These discussions were led by a Moderator, assisted by two people. The moderators and assistants briefed on the study and a translator assistant could speak in French and the local language. The discussions were guided by the Moderator through an open discussion grid established and validated by a committee.

- Individual interviews with resource peoples: 05 focal points nutrition (health workers) health areas; 05 Community Health workers (CHW) and 05 Mothers. Interviews were conducted face-to-face in a location chosen by the respondent through a semi-structured discussion grid.

- Stories of life with breastfeeding women, women whose children attend ambulatory nutritional centers were collected face-to-face and recorded in audio support in a quiet place chosen by the respondent and out of sight.

- Observations in children's households

The transcript was made by the moderator and an investigative supervisor. The translators were selected on the basis of the mastery of the local language of the site to collect the data and French; Availability during the survey respect for the ethics of Cameroon's health system; respect for the customs and traditions of the people of the community.

The survey focused on gathering several sources of information for the most accurate and reliable triangulation possible (focus-groups; semi-direct discussion, and direct observation of households and health facilities). Reviews of literature on previous studies in the far north region, and other studies on the determinants of malnutrition in Cameroon. 


\subsection{Data analysis}

For the analysis of data from focus groups and semi-direct interviews we used Krueger's method known as "long table" which consisted of identifying thematically or by questions, any word transcribed in the verbatim of the focus groups and semi-direct interviews. We chose to base ourselves on the themes, a method used by Seguin J. (2010). Each word was transcribed when it was relevant, it was classified according to the themes that correspond to those of the grid. The analysis therefore looked at the frequency of similar responses to the same question in 35 target women selected for group discussions and 10 semi-direct interviews. The analysis of these data was supported by observations made at the household level.

\section{Results and Discussion}

\subsection{Results}

A total of 05 focus groups (07 mothers per group) of 35 mothers, 15 semi-directing interviews were organized with 05 mothers including ex-malnourished children; 05 CHW and 05 focal points nutrition. The total number of women was 43 and men. The average age of pa. rticipants was 28 years in focus groups (FG) and 38 years in individual interviews (II); the average age of women in the survey was 29 years and 44 for men (Table 1). According to the rules, 32 Christians against 18 Muslims participated in the study (Table 2).

Table 1. Distribution of Participants per District, Gender and Average Age

\begin{tabular}{|l|c|c|c|c|c|c|}
\hline Districts & Mothers & Men & $\begin{array}{c}\text { average } \\
\text { Age. FG }\end{array}$ & $\begin{array}{c}\text { average } \\
\text { Age. II }\end{array}$ & $\begin{array}{c}\text { average } \\
\text { of age } \\
\text { mothers }\end{array}$ & $\begin{array}{c}\text { average of } \\
\text { age men }\end{array}$ \\
\hline Guere & 09 & 01 & 36,6 & 34,3 & 36 & 39 \\
\hline karhay & 08 & 02 & 22,1 & 35,7 & 22 & 45 \\
\hline Maga & 09 & 01 & 39,3 & 38,0 & 39 & 42 \\
\hline Vele & 09 & 01 & 21,6 & 43,7 & 26 & 48 \\
\hline Yagoua & 08 & 02 & 19,7 & 40,3 & 21 & 46 \\
\hline Total & $\mathbf{4 3}$ & $\mathbf{0 7}$ & $\mathbf{2 7 , 9}$ & $\mathbf{3 8 , 4}$ & $\mathbf{2 9}$ & $\mathbf{4 4}$ \\
\hline
\end{tabular}

Table 2. Distribution of Participants per Sex and Religion

\begin{tabular}{|l|c|c|c|c|c|}
\hline & CHW & $\begin{array}{c}\text { Breastfeeding } \\
\text { women }\end{array}$ & $\begin{array}{c}\text { Mothers of ex- } \\
\text { malnourished }\end{array}$ & $\begin{array}{c}\text { Nutrition } \\
\text { Focal Point }\end{array}$ & Total \\
\hline Mothers & 03 & 35 & 05 & 00 & 43 \\
\hline Men & 02 & 00 & 00 & 05 & 07 \\
\hline Christians & 04 & 22 & 03 & 03 & 32 \\
\hline Muslims & 01 & 13 & 02 & 02 & 18 \\
\hline
\end{tabular}

\section{a. Geographical Context}

Group discussions and community discussions show that the Mayo-Danay division is facing the need for food processing, storage and transport infrastructures. Most of the towns are landlocked in the rainy season and almost inaccessible, except in the city of Yagoua, the division. There is also a lack of infrastructure in these areas for small markets and buildings for food processing units. These conditions do not promote the conservation and food storage that mothers refer to, which would cause the early and low-cost liquidation of food, and the exposure of people to famine and poverty only a few months after harvest. 
Mothers report unavailability of arable land. According to the latter, the installation in some localities of large agricultural companies such as the Rice Expansion and Modernization Corporation (SEMRI) in the Vele Health District is one of the reasons. Indeed, SEMRI has acquired a large part of the arable land, the residents of the majority former farmers, although having been compensated have remained in the premises but do not own arable land. Some families move to neighboring Chad to make fields because of a lack of arable land in the community. A local resident said, "We don't have land to cultivate, we can't do the fields, everywhere it's the SEMRI field... Others go to see their brothers on the other side of the Logone to ask for the land to make the field" A mother of Vele.

\section{b. Seasonal Background}

Although the rainy season lasts only four to five months in the Mayo Danay area, the rains cause natural disasters such as floods. The Mayo-Danay faces repetitive flooding in several areas of the Mayo Danay division, the mostly clay soil takes time to absorb water. The recent floods were directly related to the deterioration of the Logone dam and had caused many internally displaced people in the districts of Vele and Maga. Although the study was done in the dry season, the area was still suffering the consequences of past floods, such as Internally Displaced People from Maga district in the Pouss health area specifically in Sokolaye village where several cases of children have been reported malnourished with parents who still do not have arable land and live off small businesses. A mother, internally displaced in Sokolaye says "We came here because we fled the flood, we live badly, we can't make the field, we came to live here but no one gave us land to cultivate. We often wind little things to buy millet to prepare for everyone".

\section{c. Security Background}

The context of insecurity in the Far North is mainly that of terrorism due to the Islamic sect Boko Haram. Although the Mayo-Danay area had not yet reported terrorist attacks, the area is still suffering the consequences of the crisis in the region. Indeed, several people in the area carried out economic activities (trade, transport, etc.) either in Nigeria, on the NigeriaCameroon border or on the Cameroon-Chad border, and thus supplied their families with food and financial resources. Instability caused by the Boko Haram sect in the border area has forced many people who were essential laborers for the household economy to return to their areas of origin, sometimes abandoning their goods and savings. Thus, people who were once a labor force (source of income) for households, have become an additional burden, in a context of food insecurity. Several households in Mayo-Danay are reported to be facing this phenomenon, which plays in favor of food shortages in the household. The situation of insecurity caused by the Boko Haram sect weakens cross-border economic exchanges. The Mayo-Danay, which was a border area with Chad before the crisis, was a strategic point in the transit of products from Nigeria and other Cities of Cameroon to Chad. With the arrival of terrorism, trade with Nigeria in the region has plummeted, weakening the economy in the area.

\section{d. Socio-demographic Data}

The observation in the 35 households shows that the majority of households in the division of Mayo-Danay had four people. However, some households have up to ten (10) heads sometimes beyond. The majority of households included two (02) children under the age of five. During the group discussions, we found that the household economy is based on the mother. The rest of the household does not contribute much to the common needs of the household. The larger the size of the household, the more the workload increases for the 
mother, in the majority of cases, to find and make household meals. This fact is more observed in Christian-obedient households, as evidenced by a mother of Vele. "We're six people at home, and everyone eats what I prepare... My husband, his money is for drinking, I'm the one who prepares and I'm still looking for what I need to prepare and when he comes home at night he has to eat. I have to work and prepare or we'll sleep without eating. Here it is the women who do everything, the husbands do not ration, even when he sells the rice he goes to drink with the money." Another in a village in Guibi argues that "In some cases it is the woman who has all the burden of the household and can't get out of it. The man is concerned elsewhere, the well-being of the family is not his business. At the moment the woman is struggling to prepare the family for what is within her reach and at the limit of her means."

\section{e. Agricultural and Agro-pastoral Production}

During the semi-direct interviews, several community members stated that livestock is widespread in their communities. The types of livestock commonly cited included: the raising of small livestock, pigs and poultry. The type of breeding practiced here remains in stable to the free area, and to a small number of heads. It should be noted that households almost do not consume the animals raised, they are intended for sale to support other household and/or head of household needs.

Agriculture in the Mayo Danay division is determined by the rain seasons and availability of land. Some mothers reported having no land to cultivate, the majority of them were internally displaced. The most found crops include millet, sorghum, cowpea, onions, rice and vegetables. During the survey period we observed a variety of fruits/vegetables in the Yagoua market, mangoes, cucumbers, nuts and others.

The Mayo-Danay division is watered by the Logone River, the lakes of Guere and Maga. Fishing is widely practiced in the division. Regarding the fate of fish products, there is a disparity between district areas; in the areas of Vele, mothers said that the products of the fishery were intended for sale, this observation was made in other areas. However, in the Maga area it is accepted that some of the fishing products are consumed directly at the household level. One community member said, "In terms of food, we eat fish because of the proximity to the lake. It is important to note that much of this fishery, the food we produce, is for sale."

\section{f. Access to Safe Drinking Water and Hygiene for Children}

Access to drinking water for people, as well as water for livestock, remains precarious in most communities. After the rains, the majority of the rivers dry up, the water distribution network remains very limited and reserved for the big city of the area: Yagoua. During group discussions the majority of mothers reported systematically washing children's hands before meals, but noted the lack of use of running water and sometimes soap.

\section{g. Access to Child Health Services}

Several testimonies show that mothers and children visit health facilities during vaccination and when the child is sick, when the woman is pregnant and just after giving birth. "A mother has to go to the Health Centre with the children when you are sick or the child, while she is pregnant, while a woman has just given birth for vaccination," a mother tells KarHay in a focus group.

The majority of mothers and community members welcome the Ambulatory Nutritional Centers (ANC). Mothers feel gratitude and grateful for the care their children receive in these services. One mother testified, "It is thanks to these health facilities that our children are 
alive, we are also given advice about the food we receive, not to give to other children. We would like the state to help us more with soaps, cups, buckets, kettles." Another also said, "We are well received at the NAC, but at one point there were no inputs? the NACs are fine because the child who was sick is cured, the state gives us plumpy-nut for free to cure our children, children no longer make diarrhea in disorder. May the state continue to support us because we give birth and our generation will do so as well. The state also gives us mosquito nets, buckets, kettles and aquatab."

According to the mothers, the stock shortages that these structures sometimes experience hinder the proper care of children. The community also recommends transparent input management by health workers and mothers. "We would like to see better management in THE ANCs through a permanent supply of kit and inputs because when there is a rupture it disturbs the treatment," one of Vele's mother. "As far as ANCs is concerned, I would like the staff to give the inputs properly without affinity or relationship... Let the reception in these structures be better. The inputs must be truly intended for the sick... That the parents do not share the inputs of the malnourished child with the other brothers."

\section{h. Food Security in the Household and in Children (Food Diversity)}

The qualitative data confirmed high consumption of products from the root-and-tuber groups. In group discussions the mothers declare: "The most consumed food is the couscous of the red millet accompanied by the sauce of the bark of a tree called "Tefana" (in the local language Massa) still called long sauce because it is sticky. For those who have a little means, we add a little cowpea (white bean). On the day that someone is lucky to have dry fish, they are also added to it, but it is rare because living conditions are difficult. This meal is regularly prepared without fish or cowpea because this is what is within the reach of the population... As far as meat is concerned, there are no ways to get it... The majority of red millet and a bit of fonio are grown, which is becoming increasingly rare," says a mother of Guibi. Another states, "Red millet with 'Tefana' is the most consumed meal in the community. When it's very strong sometimes, you can't even get the millet, you prepare the sauce without complement... There is no choice to make, it is necessary for the community for lack of means, we are poor! We grow red millet." According to mothers, in poor households, access to group foods of meat, fish and eggs, for protein and iron remains low and occasional, as evidenced by mothers during the discussions. A mother of KarHay says, for example, "We enjoy events such as the feast of the feo-tied (Chicken), the traditional feasts, funerals, Christmas where we take advantage of these sacrifices to eat the meat."

Focus-groups and individual interviews show that the foods consumed in the communities of Mayo-Danay include, among others, Red Mil, Tasba, Neyebe (white bean), Téfana, foléré, Gombo (fresh and dry), Lalo, fish, meat, milk. White beans (cowpea) and rice are grown in several areas of the Mayo Danay division but are not widely consumed by households, these foods are more for sale than for internal consumption. Red mil is widely consumed by the majority of households mixed with okra sauces (dry or fresh) and Téfana. Food practices vary according to standard of living, area, crops and perceptions. Food in households is conditioned by financial means and the environment in which we live. The population feeds on what is within the reach of each household. Communities near lakes (Maga, Gueré) consume more fish than other communities. Households in Yagoua (urban area) consume a little more meat.

"Fish is regularly eaten in our households because we are in an area of the lake. The fish is eaten in all forms, whether fresh or dried according to the means at our disposal. The fish is sometimes accompanied by simple rice or made in couscous. For some women if there were enough financial means one would eat meat such as the legs of the oxen made in broth, 
"says a mother of Maga. "For some we eat a lot redder millet because it's our food," another mother tells Kar-Hay. Another finding is that mothers want to vary meals in the household, but they are faced with a lack of resources. "We want to vary our food, but we are faced with the financial reality." A mother of Vele.

\subsection{Discussion}

The Mayo Danay division is constantly facing increased needs for agricultural storage, exchange or processing infrastructure. Most of the localities in the Mayo Danay division are landlocked and almost inaccessible, except in the division of Yagoua. As in most division and boroughs in the far north region, there is a lack of conservation methods, infrastructure for processing agricultural commodities or for the flow of associated products. In addition, there is a reduction in the area of arable land for the benefit of large companies. A study realized by Goudoum in 2017, shown that the productions are stored in temporary or permanent attics. These artisanal techniques demonstrate the low level of access to modern food conservation techniques (Goudoum and Ngamo, 2017).

The Mayo-Dany and its surroundings face repeated flooding in several areas of the Mayo Danay division, the mostly clay soil takes time to absorb water. Flooding linked to the deterioration of the Maga dam and had caused many internally displaced people in the health districts of Vele and Maga. Rodents, locusts that devastate the fields and the scarcity of rainfall adds to a pronounced poverty at the household level. The work of B. Djiangoué conducted in 2017, already highlighted the impact of floods, rodents and locusts in the study area. According to the authors, since the late 1990s and precisely 1998, populations residing in the area of influence of the Logone and Benoué rivers have been under heavy flood control. The latter reoffend at a five-year, three-year and biennial rate, each time claiming many victims (Djiangoué ,2017).

The precarious security situation at the Cameroon-Nigeria and Cameroon-Chad borders due to the terrorist threat has forced its countries to close borders, limiting food trade and reducing household income sources. Indeed, the deleterious security climate in the Far North region has exacerbated the difficulties of a region already facing significant socio-economic challenges. The pillars of the local economy (livestock, agriculture, cross-border trade and tourism) are now severely shaken by the Boko Haram phenomenon. According to the same source, most of the border transit points (Dubble, Amchidé-Banki) have been closed (Ntuda Ebode and coll., 2017).

The burden of household size in terms of food rations is borne by women with very limited incomes. The work of FZ Azzaoui and coll,, confirmed that there is a significant correlation between malnutrition in children and household size (Azzaoui FZ and coll., 2008).

Access to drinking water in the Mayo Danay division remains precarious as in the far north region as a whole, this could be explained by drying up of water points and supply streams in the dry season. Food practices vary according to standard of living, area, crops, perceptions or taboos and low household income. In addition, pastoral production is more for sale, not domestic consumption. This makes it difficult, food diversification in the household. During group discussions the majority of mothers reported systematically washing children's hands before meals consumption, but noted the lack of use of running water and sometimes soap. The work of Sobze Sanou M and coll., in 2020 showed that children from multiminority households were at greater risk of developing chronic malnutrition (Sobze Sanou and coll., 2020). This poverty is characterized by the deprivation of children's drinking water, access to health services; sanitary hygiene; healthy nutrition etc. Our research has shown that households use standing rainwater as the main source of household drinking water. 
According to Nounkeu and coll., study, $96 \%$ of children use spring water in their households. This testifies to the low access to water in the regions of Cameroon (C. Nounkeu and coll., 2019). A study conducted by Benjamin A.C. and coll., in the northern region showed that $44.3 \%$ of children had at least one episode of diarrhea (Benjamin Azike and coll., 2019). This view is reinforced by the result of the study conducted by Gorham and coll. in rural areas of the far north Cameroon region where the incidence of diarrhea among children varied from camp to camp (31.3\%) the causes are the consumption of non-potable water (Tyler J. Gorham and coll., 2017). According to the conceptual framework of child malnutrition designed by UNICEF, disease is one of the direct causes of malnutrition (UNICEF, 2013). This could be a major factor in the high prevalence of malnutrition in the study area. Figure below shown the process.

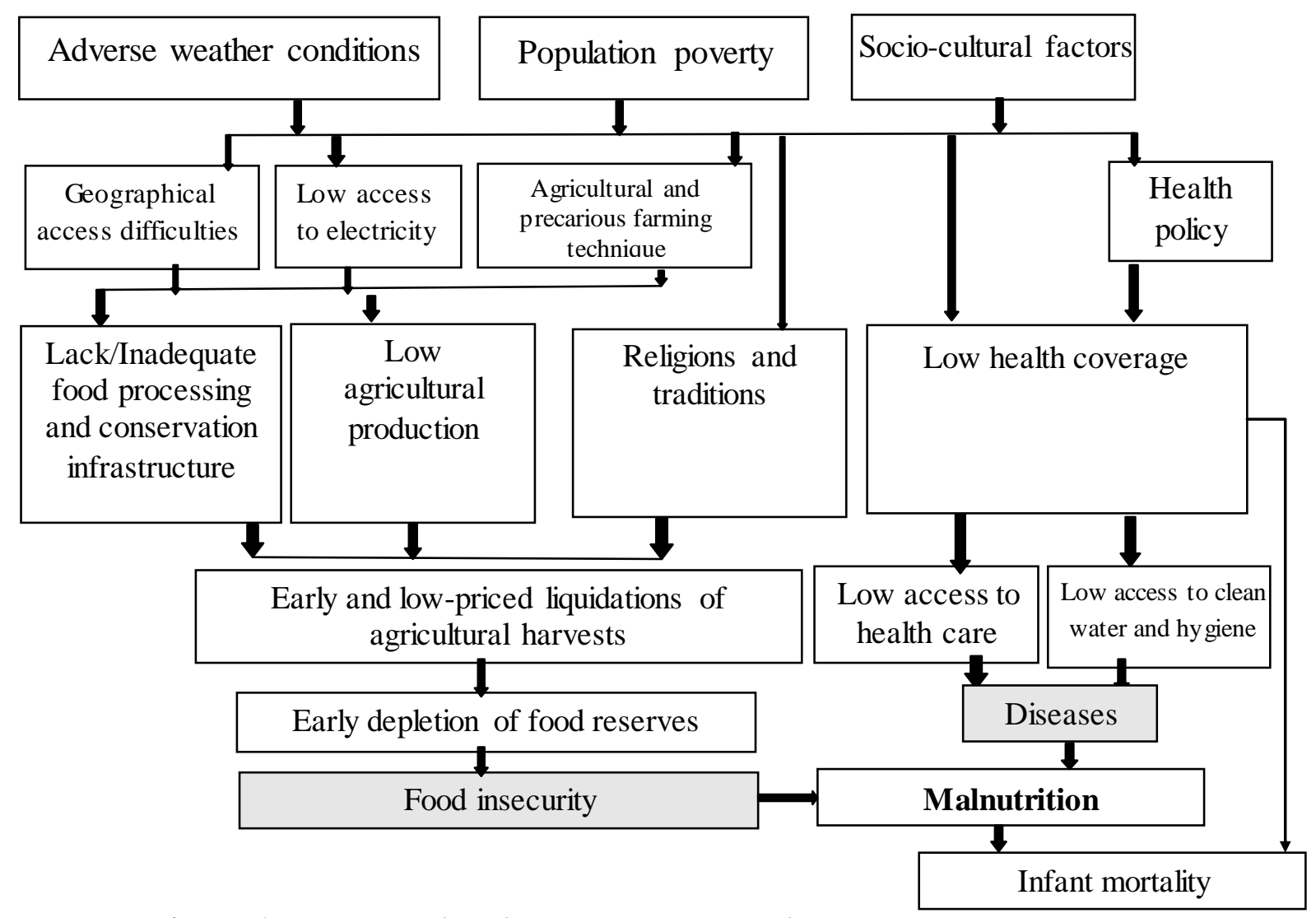

Figure 1. Conceptual Malnutrition Framework in Mayo Danay, Cameroon

Mothers in the communities in our study reported high attendance in maternal and child health services (sick children and/or mothers, antenatal consultations, vaccinations, postpartum) for its benefits and child benefits. This constant attendance was also recorded by Sobze and coll., in the study area with vaccination coverage of $81.52 \%$; and $82.64 \%$ vitamin A supplementation demonstrating access to child health services (PAM, 2018).

The results show that the food consumed in the communities of Mayo-Danay is mostly poor, including the Red Mil; Tasba; Cowpea (white bean), Tefana, foléré, Gombo (fresh and dry), Lalo, fish, meat (reserved only for a middle class), milk. White beans (cowpea) and rice are grown in several areas of the Mayo Danay division but are not widely consumed by households, these foods are more for sale than for internal consumption. Red millet is widely consumed by the majority of households mixed with okra sauces (dry or fresh) and Téfané. According to the Office for the Coordination of Humanitarian Affairs, insecurity has also 
hampered population movements and limited access to markets, resulting in depletion of stocks and increasing the vulnerability of the population to acute food insecurity. Almost all households (98\%) who are moderately food insecure have poor or limited food consumption; $7.6 \%$ of households sold animals in the Far North in an unusual way to meet their food needs (OCHA,2019). The work of Sobze Sanou M. and coll., showed a high consumption of cerealtuber-root (98.9\%); meat-fish (73.1\%); legumes and nuts $(63.6 \%)$ and fruit-vegetables $(62.9 \%)$ in the study area (Sobze Sanou and coll., 2019). According to the same study, only $51.6 \%$ of children receive a diversified diet in the Mayo Danay. Apart from a few imported products (rice, pasta), the level of supply has generally decreased in the Far North region, mainly due to the decline in production, strong demand from other areas (sp sorghum, sorghum SS) and brewing companies (corn, peanuts) and depletion of stocks. Compared to the 2016/2017 campaign, grain prices are on the rise in this region. This price increase is mainly the result of the storage of cereals by private operators who resell them during the welding season or export them to Chad and Sudan, creating shortages in the local market (PAM, 2018).

\section{Conclusion}

The causes of malnutrition in the Far North region are multifactorial (Figure 1). These factors can be staggered to three levels. (1) The primary level conditioned by the environment (climate condition); economics (population poverty) and socio-cultural. (2) The second is conditioned by the unavailability of food conservation and processing infrastructures; agricultural production; health coverage. (3) The tertiary degree is coordinated by food security and access to health and hygiene care (illness). Strategies to fight against malnutrition in the study area must be targeted to integrate local and sustainable development; Food security access to health care and communication for a change in food practices.

\section{References}

A. Goudoum et Leonard ST. Ngamo. Insécurité alimentaire et résilience par la protection des denrées en zone soudano-sahélienne du Cameroun. Edi CAD ; 2017, p155-180

Alhaji A. Aliyu, Olugbenga O. Oguntunde, Tukur Dahiru and Tajudeen Raji, 2012. Prevalence and Determinants of Malnutrition among Pre-School Children in Northern Nigeria. Pakistan Journal of Nutrition, 11: 1092-1095. DOI: 10.3923/pjn.2012.1092.1095

Azzaoui F-Z, Ahami A.O.T, Khadmaoui A. 2008, Relation entre les facteurs socioéconomiques, environnementaux et la malnutrition : Cas d'enfants âgés de 6 à 8 ans de la plaine du Gharb (Nord-Ouest Marocain), Antropo, 17, 1-5. www.didac.ehu.es/antropo

B Djiangoué. Inondations et vulnérabilité des systèmes de production agricole : cas du Logone (Extrême-Nord) et de la Bénoué (Nord) Cameroun. Edi CAD ; 2017, p35-53

Barbieri M., 1991, Les déterminants de la mortalité des enfants dans le tiers-monde, Les dossiers du CEPED n ${ }^{\circ} 18$, CEPED, Paris, 40p.

Benjamin AZIKE CHUKUWCHINDUN, André Pascal GOURA, Landry BITA'A BEYALA, Anthony NJIMBIA CHEBE, André Izacar Gaël BITA, Joliette AZAKOH NGUEFACK, Jérôme ATEUDJIEU, Pratiques alimentaires des mères et malnutrition infantile dans le district de santé de Pitoa : Etude cas-témoin. Budapest International 
Research in Exact Sciences (BirEx) Journal Volume 1, No 4, October 2019, Page: 144155 e-ISSN: 2655-7827 (Online).

Carole Nounkeu, Joseph Kamgno, Jigna Dharod. Assessment of the relationship between water insecurity, hygiene practices, and incidence of diarrhea among children from rural households of the Menoua Division, West Cameroon, Journal of Public Health in Africa 2019; volume 10:951 doi:10.4081/jphia.2019.951

Institut National de la Statistique (INS), et ICF. 2019. Enquête Démographique et de Santé du Cameroun 2018. Indicateurs Clés. Yaoundé, Cameroun, et Rockville, Maryland, USA : INS et ICF

International Food Policy Research Institute (IFPRI), 2014. Global Nutrition Report 2014: Actions and Accountability to Accelerate the World's Progress on Nutrition. Washington, DC. ISBN: 978-0-89629-564-3, DOI: http://dx.doi.org/10.2499/9780896295643

Kadam A.M., 2007. Les déterminants de la malnutrition des enfants de moins de cinq au Tchad, Mémoire de DESSD en Démographie, IFORD, Yaoundé point

Keino S, Plasqui G, Ettyang G, van den Borne B. Determinants of stunting and overweight among young children and adolescents in sub-Saharan Africa. Food and Nutrition Bulletin. 2014 Jun;35(2):167-178. DOI: 10.1177/156482651403500203.

Martin Sobze Sanou, Andre Izacar Gael Bita, Ghyslaine Bruna Djeunang Dongho, Benjamin Azike Chukuwchindun, Armand Tiotsa Tsapi, Isidore Sieleunou, Germaine Sylvie Nkengfack Nembongwe. Multidimensional Poverty and Acute Malnutrition of Children in Households of Mayo-danay Division, Cameroon. International Journal of Nutrition and Food Sciences 2020; 9(1): 25-32. doi: 10.11648/j.jpnfs.20200901.15.

MINSANTE, UNICEF. 2018. Enquête nutritionnelle anthropométrique et de mortalité rétrospective (SMART) dans les régions de l'Extrême-Nord, du Nord, de l'Adamaoua et à l'Est, septembre 2017 ; Yaoundé, Cameroun.

MINSANTE, UNICEF, 2019. Synthèse Rapport Résultats SMART 2019. Ministère de la santé publique du Cameroun, Yaoundé.

Ntuda Ebode JV, M Bolak Funteh, Mbarkoutou Mahamat H, Nkalwo Ngoula JL. Le conflit Boko Haram au Cameroun Pourquoi la paix traîne-t-elle ? Friedrich Ebert Stiftung, Yaoundé (Cameroun), 2017.

OCHA, Cameroun Insécurité alimentaire et malnutrition. 2019.[Accessible le 10/11/2020] sur https://www.humanitarianresponse.info/sites/www.humanitarianresponse.info/files/doc uments/files/cmr_snapshot_insecu_ali_malnut_v2.pdf

Pemunta, N.V. and Fubah, M.A, ${ }^{\circ}{ }^{\circ}$ Socio-cultural determinants of infant malnutrition in Cameroon, Journal of Biosocial Science, 1-26. April 2014.

Programme Alimentaire Mondiale, Cameroun : suivi de la sécurité alimentaire. Bulletin $\mathrm{N}^{\circ} 4$, Février 2018 ;

Ramadhani Nainggolan, Evawany Y. Aritonang, Etti Sudaryati. Relationship of Child Individual Factors with Stunting Incidence in Children Aged 24-36 Months at Serdang Bedagai District. Britain International of Exact Sciences (BIoEx) Journal; January 2020; ISSN: 2686-1208 (Online), 2686-1216 (Print)Vol. 2, No. 1, January 2020, Page:436-441

S. Ngo Um-Sap, H. Mbassi Awa, O. Hott, P. Tchendjou, A. Womga, A. Tanya, P. Koki Ndombo, Pratique de la diversification alimentaire chez les enfants de 6 à 24 mois à Yaoundé : relation avec leur état nutritionnel, Archives de Pédiatrie, Volume 21, Issue 1, 2014, Pages 27-33, ISSN 0929-693X, https://doi.org/10.1016/j.arcped.2013.10.015.

Sobze Sanou Martin, Bita Andre Izacar Gaël, Djeunang Dongho Ghyslaine Bruna, Sieleunou Isidore, and Nkengfack Nembongwe Germaine Sylvie, "Food Profiles and Exposure to 
Acute Malnutrition among Children Under-five in the Department of Mayo-Danay, Cameroon." Journal of Food and Nutrition Research, vol. 7, no. 11 (2019): 759-765. doi: $10.12691 / \mathrm{jfnr}-7-11-1$.

Titilola B. Balogun, Alhassan M. Yakubu, Recent Illness, Feeding Practices and Father's Education as Determinants of Nutritional Status among Preschool Children in a Rural Nigerian Community, Journal of Tropical Pediatrics, Volume 61, Issue 2, April 2015, Pages 92-99, https://doi.org/10.1093/tropej/fmu070

Tyler J. Gorham, Joshua Yoo, Rebecca Garabed, Arabi Mouhaman and Jiyoung Lee. Water Access, Sanitation, and Hygiene Conditions and Health Outcomes among Two Settlement Types in Rural Far North Cameroon; Publish in International Journal Environmental Research and Public Health, 2017, 14, 441; doi:10.3390/ijerph14040441.

UNICEF, Améliorer la malnutrition de l'enfant, un objectif impératif et réalisable pour le progrès mondial. Fonds des Nations Unies pour l'enfance (UNICEF) ; 2013, p132

UNICEF, 1998. La situation des enfants dans le monde, la malnutrition : causes, conséquences et solutions. L'urgence silencieuse.

UNICEF, 2013. AMÉLIORER LA NUTRITION DE L'ENFANT : Un objectif impératif et réalisable pour le progrès mondial. Fonds des Nations Unies pour l'enfance, United Nations Plaza, New York, 10017, États-Unis, 2013

UNICEF, 2019. La situation des enfants dans le monde 2019, résumé analytique : Bien grandir dans un monde en mutation.

UNICEF, 2018. Publication du rapport sur la nutrition mondiale 2018 : Si la malnutrition atteint un niveau inacceptable et touche tous les pays du monde, il existe aujourd'hui une opportunité d'y mettre fin. 